Campos Neutrais - Revista Latino-Americana de Relações Internacionais

Vol. 1, No 3, p. 05-o8, Setembro- Dezembro de 2019

\title{
Um ano de vida atribulado
}

\section{Hemerson Luiz Pase ${ }^{1}$}

A Revista Latino-Americana de Relações Internacionais - Campos Neutrais chega ao final do seu primeiro ano de vida, mantendo a regularidade quadrimestral proposta. Esse feito seria menos saudado se não vivêssemos num momento de tamanha dificuldade para as universidades públicas e para a ciência. Manter um veículo de divulgação científica e acadêmicaatualizado não é fácil ainda mais num momento tão atribulado no país onde o governo federal desprestigia sistematicamente o conhecimento científico.

Outra importante dificuldade é o próprio sistema de avaliação Qualis Capes que dificulta a consolidação de novas revistas, principalmente aquelas publicadas por universidades e / ou campi periféricos.Essa dificuldade é metodológica, pois a forma de avaliação do sistema Qualis estimula que pesquisadores consolidados apresentem suas propostas para revistas bem avaliadas e os pesquisadores iniciantes tenham muito pouco espaço nessas revistas. A face perversa para as revistas novas ou „male avaliadas é a pouca atratividade para pesquisadores e autores consolidados, dificultando sua melhoria na avaliação e mantendo um polo dominante restrito e bastante específico dentro do campo científico, particularmente na área das ciências humanas e sociais.

Se não existissem outras razões para a manutenção desse status quo, pois jogar o jogo permite a disputa dos recursos disponíveis, o corte nos recursos para a ciência e a universidade implementado pela atual governo (que chega a casa dos $18 \%$ no orçamento de 2020) deveria nos impulsionar a fazer algo diferente, a rompermos com a nossa inércia de continuar fazer o que sempre fazemos: atualizar o lattes, dar aulas, brigar com os colegas pelos recursos para diárias e passagens. Enfim, estamos numa situação de exceção que exige novas posturas.

Já é inócuo discutir a consolidação da democracia e do sistema político no Brasil e no mundo, que já falharam. Quando os colegas economistas e cientistas políticos

\footnotetext{
${ }^{1}$ Doutor em Ciência Política. Professor do Curso de Graduação em Relações Internacionais e do Programa de Pós-Graduação em Direito e Justiça Social da Universidade Federal do Rio Grande (FURG). Editor da Revista Latino-Americana de Relações Internacionais - Campos Neutrais. E-mail: hemerson.pase@gmail.com
} 
Campos Neutrais - Revista Latino-Americana de Relações Internacionais

Vol. 1, No 3, p. 05-08, Setembro- Dezembro de 2019

afirmam que as instituições estão funcionando, a pergunta que deve ser feita é: funcionando para quê e para quem? Como diz um grafite muito inteligente 'quando teníamos todas las respuestas, cambiaram las preguntas'.

Muito embora essa situação não anuncie seu limiar a Revista Campos Neutrais se mantém firme no rumo da consolidação na Universidade Federal do Rio Grande, no Campus de Santa Vitória do Palmar e na área do conhecimento das relações internacionais e a publicação do Número 3 do Volume 1 permitirá que possamos submeter a revista para ser avaliada.

Este número conta com cinco artigos e uma resenha, todos de altíssimo nível.

No primeiro artigo, Os desafios da previdência social no mundo: uma polaroide desde América Latina, Nelson Dionel Cardozo problematiza a "crise das pensões", que tem sido analisada na literatura majoritariamente sob a hipótese de que o envelhecimento da população e as alterações nos mercados de trabalho tornarão insustentável o pagamento das pensões públicas no futuro. Isto é explicado pela diminuição do número de trabalhadores e pelo aumento do número de idosos na pirâmide populacional. De outro lado, de forma crítica e não hegemônica são apresentadas propostas analíticas que refutam a ideia da "crise previdenciária". Finalmente, se examina brevemente como o consenso ortodoxo se traduziu na introdução das contas de capitalização individual na América Latina e como o seu fracasso provocou uma nova onda de reformas. Este novo período incluiu medidas para aumentar a cobertura dos idosos, a criação de fundos públicos e melhorias no funcionamento do pilar privado.

O segundo texto, Liberalismo e Conservadorismo nos Estados Unidos: construção e evolução no século $\mathbf{X X}$, escrito por Camila Vidal apresenta um interessante debate sobre a polarização partidária estadunidense. Para a autora, partido e ideologia estariam mais alinhados entre si resultando em distanciamento entre os partidos políticos. Entretanto, a dicotomia Conservadorismo x Liberalismo, hoje enraizadas nos partidos a ponto de serem usadas como sinônimos desses, fazem parte de construções distintas, cujas construções demonstram que o "Liberalismo" emerge no meio político para lidar com questões práticas e está associada diretamente às políticas do New Deal, enquanto o "Conservadorismo" é construído no meio acadêmico com 
Campos Neutrais - Revista Latino-Americana de Relações Internacionais

Vol. 1, No 3, p. 05-o8, Setembro- Dezembro de 2019

aporte do empresariado e apoio de lideranças evangélicas na tentativa de articular uma frente oposta à essas mesmas políticas.

No terceiro artigo, Estudos de caso sobre formação de agenda no Brasil, Damasio Duval Rodrigues Neto, Márcio Barcelos e Rodrigo Serpa Pinto apresentam as principais teorias sobre formação de agenda e de estudos que as aplicam em casos concretos no Brasil. Os autores objetivam realizar uma aproximação da literatura sobre formação de agenda com o ambiente da formulação de políticas públicas no país concluindo que os conceitos de imagem de política, janela de oportunidade e empreendedor de políticas podem ser utilizados para analisar a formulação de políticas no Brasil.

O quarto artigo, A crise política no Brasil e o impeachment de Dilma Rousseff em 2016, escrito por Dejalma Cremoneseanalisa as ações sociais e políticas que levaram ao afastamento da presidente Dilma Rousseff da Presidência da República no ano de 2016. O autor sustenta que o modelo político-econômico protagonizado pelo governo de FHC, marcado por mudanças nas áreas fiscal, cambial e monetária, e de Lula, sustentado no consumo e no crédito subsidiado, trouxeram avanços pontuais significativos, mas, de certa forma, esgotaram-se. A ausência de uma coalizão política forte no governo de Dilma Roussef, aliada à crise econômica brasileira, foram determinantes para a eclosão de protestos generalizados promovidos por movimentos sociais conservadores por todo o país no ano de 2013 em diante. Esse cenário de instabilidade social, política e econômica, somado à infidelidade do PMDB ao governo de Dilma Rousseff, contribuíram para o seu afastamento da Presidência da República no dia 31 de agosto de 2016.

No quinto texto, Escândalos políticos de corrupção e socialização política dos jovens no Sul do Brasil, Jennifer Azambuja de Morais, Henrique Souza da Silva e Ana Julia Bonzanini Bernardi, analisam os escândalos políticos de corrupção e a Operação Lava-Jato que culminaram como o processo de Impeachment da presidente Dilma Rousseff. As autoras objetivam analisar a relação entre o clima de corrupção política e a formação do tipo de cultura política dos jovens da região Sul do país. Para tanto, foram utilizados dados de pesquisa realizada pelo NUPESAL/UFRGS, entre 2015 e 2016, nas três capitais da região Sul, quais sejam, Porto Alegre, Florianópolis e Curitiba, com jovens de 13 a 24 anos, de escolas públicas e privadas de ensino médio. As análises preliminares permitem a interpretação de que os jovens internalizaram fortemente a 
Campos Neutrais - Revista Latino-Americana de Relações Internacionais

Vol. 1, No 3, p. 05-o8, Setembro- Dezembro de 2019

relação campo político-corrupção, apresentando atitudes e comportamentos hostis em relação às instituições políticas.

Por último e não menos importante José Renato Ferraz da Silveira nos apresenta a resenha da obra breve, porém, representativo de seu coerente e sistemático pensamento político e filosófico de Slavoj Žižek, Primeiro como tragédia, depois como farsa. Neste livro Žižek problematiza os tempos contemporâneos ligados às duas crises que atingiram o mundo: os ataques de 11 de setembro de 2001 e a crise financeira de 2008 cujo impacto revela o declínio e o fim do ciclo das promessas da democracia liberal e o ressurgimento de uma nova esquerda.

Boa leitura! 